\title{
Development and Validation of a Chromatography Method Using Tandem UV/Charged Aerosol Detector for Simultaneous Determination of Amlodipine Besylate and Olmesartan Medoxomil: Application to Drug-Excipient Compatibility Study
}

\author{
Ariadne M. Brondi, Jerusa S. Garcia, and Marcello G. Trevisan \\ LACFar-Institute of Chemistry, Federal University of Alfenas (UNIFAL-MG), Alfenas, MG, Brazil \\ Correspondence should be addressed to Marcello G. Trevisan; mgtrevisan@gmail.com
}

Received 24 August 2017; Accepted 22 October 2017; Published 17 December 2017

Academic Editor: Josep Esteve-Romero

Copyright (c) 2017 Ariadne M. Brondi et al. This is an open access article distributed under the Creative Commons Attribution License, which permits unrestricted use, distribution, and reproduction in any medium, provided the original work is properly cited.

\begin{abstract}
A study was carried out to investigate compatibility of amlodipine besylate and olmesartan medoxomil with a variety of pharmaceutical excipients. Both drugs are antihypertensive agents that can be administered alone, in monotherapy, or in pharmaceutical association. The studies were performed using binary and ternary mixtures, and samples were stored for 3 and 6 months at $40^{\circ} \mathrm{C}$ under $75 \%$ relative humidity and dry conditions. For this study, a method based on high-performance liquid chromatography (HPLC) was developed and validated for the simultaneous determination of amlodipine besylate and olmesartan medoxomil in samples from pharmaceutical preformulation studies using diode array detector (DAD) and charged aerosol detector (CAD). The runtime per sample was $10 \mathrm{~min}$ with retention time of $7.926 \mathrm{~min}$ and 4.408 min for amlodipine and olmesartan, respectively. The validation was performed according to $\mathrm{ICH}$ guidelines. The calibration curve presents linear dynamic range from 12 to $250 \mu \mathrm{g} \mathrm{mL} \mathrm{m}^{-1}$ for amlodipine and from 25 to $500 \mu \mathrm{g} \mathrm{mL} \mathrm{m}^{-1}$ for olmesartan with coefficient of determination $\left(R^{2} \geq 0.9908\right)$ while repeatability and reproducibility (expressed as relative standard deviation) were lower than $1.0 \%$. The excipients such as corn starch, croscarmellose sodium, magnesium stearate, polyvinyl alcohol, talc, polyvinylpyrrolidone, lactose monohydrate, and polyethylene glycol showed potential incompatibilities after accelerated stability testing.
\end{abstract}

\section{Introduction}

Amlodipine besylate (AMLO), CAS = 111470-99-6, 3-ethyl5-methyl-2-(2-aminoethoxymethyl)-4-(2-chlorophenyl)-1, 4-dihydro-6-methyl-3,5-pyridinedicarboxylate benzenesulphonate, is a calcium channel blocker used in treatment of hypertension, angina pectoris, and other cardiovascular diseases. Figure 1(a) shows the chemical structure of amlodipine besylate [1-3].

Olmesartan medoxomil (OLME), CAS = 144689-63-4, 1Himidazole-5-carboxylic acid, 4-(1-hydroxy-1-methylethyl)-2propyl-1-[[2' -(1H-tetrazol-5-yl)[1,1'-biphenyl]-4yl]methyl]-, (5-methyl-2-oxo-1,3-dioxol-4-yl) methyl ester, is a prodrug that is subjected to enzymatic hydrolysis, and its active product, olmesartan, is an angiotensin II receptor blocker
(ARB) used in treatment and prophylaxis of hypertension. Figures 1(b) and 1(c) show the chemical structure of olmesartan medoxomil and of its active product, olmesartan [4-7].

At the treatment of hypertension, the monotherapy has adequate therapeutic response, but at least $70 \%$ of the patients require two or more medications for the adequate blood pressure control. For these cases, the pharmaceutical association is a proper administration of drugs [8].

The United States Pharmacopeial Convention (USP) recommends for the determination of AMLO the liquid chromatography (LC) assay using a mobile phase containing methanol, acetonitrile, and buffer solution (trimethylamine and phosphoric acid, $\mathrm{pH} 3.0$ ) at the proportion of $35: 15: 50$. For the determination of OLME, the USP recommends the 
<smiles>CCOC(=O)C1=C(COCCN)NC(C)=C(C(=O)OC)C1c1ccccc1Cl</smiles>

(a)

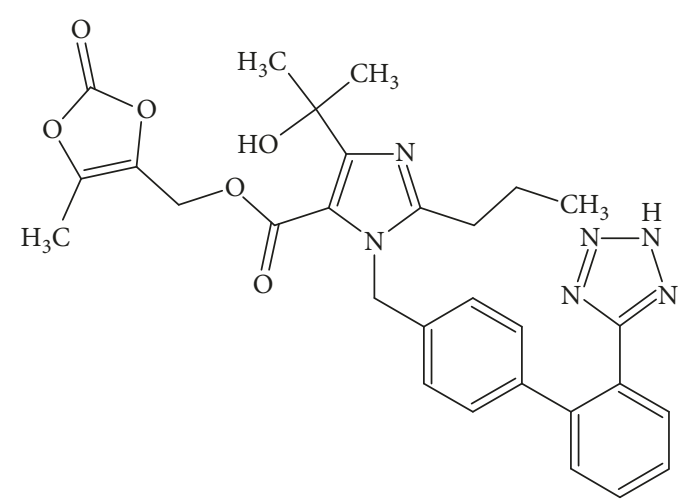

(b)

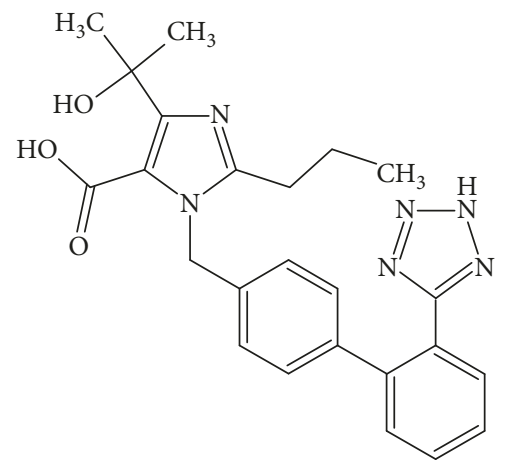

(c)

FIGURE 1: Chemical structure of (a) amlodipine besylate, (b) olmesartan medoxomil, and (c) olmesartan.

LC assay using a mobile phase containing buffer solution (phosphoric acid, $\mathrm{pH}$ 3.4) and acetonitrile at the proportion of $33: 77$ [9]. The simultaneous determination of AMLO and OLME is already reported in the literature in human plasma $[2,10]$, urine, [10] and dosage form [11-13]. However, to date, there are no reports on the use of charged aerosol detector (CAD) on determination of AMLO and/or OLME.

The CAD is a relatively recent technology, and its main characteristic is to be a universal detector for nonvolatile analytes. The response may vary according to the composition of the mobile phase, and there are some limitations about the mobile phase: these may not be saline and the solvent must be volatile. The CAD is a detector independent of the chemical structure, optical properties, and the ionization capacity of the analytes, producing a similar response for different compounds, which allows the quantification even when there is no standard availability, since the detector measures the amount of charge, which is proportional to the amount of analytes. At CAD, the HPLC eluent is nebulized by Venturi effect produced by a carrier inert gas, usually nitrogen, transforming the eluent into small droplets. The small droplets are carried by the gas flow to a drying tube where the solvent is evaporated. The aerosol formed is charged with a secondary stream of nitrogen that has passed a high-voltage platinum wire, and the charged aerosol is measured by an electrometer [14-21].

The drug-excipient compatibility study is an important step in the development of pharmaceutical dosage forms. The incompatibility of a drug with one or more excipients in a formulation can affect the stability and/or bioavailability of the active product, thereby affecting its safety and efficacy of the formulation. The drug-excipient incompatibility can be due to the covalent reaction between the drug and the excipient, and/or the excipient-promoted intrinsic degradation of the drug. This study also allows to know the type of packaging most suitable and to establish adequate conditions of storage [22-25].

The purpose of this work was to develop and validate a sensitive LC method with CAD for determination of AMLO and OLME, which could be applied to drug-excipient compatibility studies.

\section{Experimental}

2.1. Chemicals and Reagents. Amlodipine besylate and olmesartan medoxomil were supplied by Aché (Guarulhos, Brazil). The pharmaceutical excipients, such as corn starch, microcrystalline cellulose, croscarmellose sodium, magnesium stearate, titanium dioxide, polyvinyl alcohol, talc, polyvinylpyrrolidone (PVP), lactose monohydrate, and polyethylene glycol (PEG), generally used in the formulation with AMLO and OLME, were of USP grade. Acetonitrile of LC grade (J.T. Baker, USA) and extrapure ammonium acetate (Nuclear, Brazil) were used to prepare the mobile phase for LC analysis. For development and validation of HPLC-CAD method, amlodipine besylate pharmaceutical standard (SigmaAldrich, Saint Louis, USA) and olmesartan medoxomil European Pharmacopoeia Reference Standard (European Directorate for the Quality of Medicines \& Healthcare, Strasbourg, France) were used. A Master System MS2000 water purification (Gehaka, Brazil) was used to obtain ultrapure water (resistivity of $18 \mathrm{M} \Omega \mathrm{cm}^{-1}$ ).

2.2. Apparatus and Chromatographic Conditions. For HPLC analysis, liquid chromatographic system UHPLC Ultimate 3000 (Thermo Scientific Dionex, USA), consisting of an LPG3400RS pump with integrated vacuum degasser, autosampler WPS-3000RS with $100 \mu \mathrm{L}$ injector, TCC-3000RS column oven, DAD-3000RS diode array detector, and Dionex Corona ultra RS charged aerosol detector, was used. In brief, isocratic elution with the column Eclipse XDB-C18 $(4.6 \times 250 \mathrm{~mm}, 5 \mu \mathrm{m}$; Agilent, Saint Clair, USA) at room temperature $\left(25^{\circ} \mathrm{C}\right)$ employing a mobile phase consisting of ammonium acetate $\left(\mathrm{pH} 6.8\right.$ at $\left.0.5 \mathrm{~mol} \mathrm{~L}^{-1}\right)$ and acetonitrile $(40: 60, \mathrm{v} / \mathrm{v})$ was carried out. The injection volume was $10 \mu \mathrm{L}$, and the flow rate was $0.5 \mathrm{~mL} \mathrm{~min}{ }^{-1}$. Mobile phase, standard solutions, and samples were filtered through nylon filter $(0.45 \mu \mathrm{m}$; Sartorius, Göttingen, Germany) before injection into the chromatographic system. The software Chromeleon 6.8 (Thermo Scientific Dionex, Waltham, USA) was used to record chromatograms, peak quantification, and integration. This methodology was inspired by the methodology described by Qutab et al. [12]. The change in flow rate was performed to improve the chromatographic 
resolution and symmetry of the peaks, and the reduction of injection volume occurred due to the high concentrations of samples to be determined.

The optimum conditions of CAD used the acquisition rate was $10 \mathrm{~Hz}$ to have a sufficient number of data points, and the time constant filter, used to reduce the noise in chromatogram, was level 0 . The optimization of CAD conditions was performed observing the resolution and symmetry of the peaks.

2.3. Validation of the Method. Validation studies were performed according to $\mathrm{ICH}$ guidelines to characterize the proposed analytical method such as dynamic range, calibration curve, limit of detection (LOD), limit of quantitation (LOQ), accuracy, precision, and method robustness [26].

The dynamic range was selected within $15.0-250.0 \mu \mathrm{g}$ $\mathrm{mL}^{-1}$ for AMLO and $25.0-500.0 \mu \mathrm{g} \mathrm{mL}^{-1}$ for OLME. Linear and polynomial (order 2) calibration curves were obtained by plotting the peak area against the nominal concentration by least squares $[22,27]$.

To determine LOD and LOQ, comparisons between measurements of reference standard solutions at low concentrations of analyst and blank samples were performed; the LOD and LOQ were defined as signal-to-noise ratio of $3: 1$ and $10: 1$, respectively $[26,28]$.

The accuracy was determined by the recovery method. Three samples were analyzed before and after the addition of a known amount of each analyte standard solution. The precision indicates the ability of the methodology to provide reproducible results. The intraday precision was evaluated by replicates of three samples on one day, whereas the interday precision was determined over three consecutive days.

Specificity was determined by comparing any interfering peaks from the blank, pure excipients, and ternary mixtures at initial time injection and checking the peak purity by HPLC-DAD.

Small changes in chromatographic conditions such as mobile phase (proportion of acetonitrile in $60 \pm 2 \%$ ), column temperature $\left(25 \pm 5^{\circ} \mathrm{C}\right)$, and flow rate $\left(0.5 \pm 0.1 \mathrm{~mL} \mathrm{~min}^{-1}\right)$ were done to evaluate the robustness of the proposed HPLC method.

2.3. Drug-Excipient Compatibility Studies. The stability study was performed using AMLO and OLME alone, binary mixtures formed by AMLO and each selected pharmaceutical excipient at a $1: 1(\mathrm{~m} / \mathrm{m})$ ratio, binary mixtures formed by OLME and each selected pharmaceutical excipient at a $1: 1(\mathrm{~m} / \mathrm{m})$ ratio, ternary mixtures formed by AMLO, OLME, and each selected pharmaceutical excipient at a $1: 4$ : $5(\mathrm{~m} / \mathrm{m} / \mathrm{m})$ ratio, and a binary mixture formed by AMLO and OLME at a $1: 4(\mathrm{~m} / \mathrm{m})$ ratio. The mixtures were prepared using analytical balance (Shimadzu AUW220D) and submitted to a physical homogenization using a vortex for $5 \mathrm{~min}$. Each mixture was quartered into five portions. The first portion of samples was analyzed immediately. Two portions of samples were also stored for 3 and 6 months in a stability chamber at $40 \pm 0.5^{\circ} \mathrm{C}$ using a saturated $\mathrm{NaCl}$ solution (average of $75 \pm 1 \% \mathrm{RH}$ ) monitored by

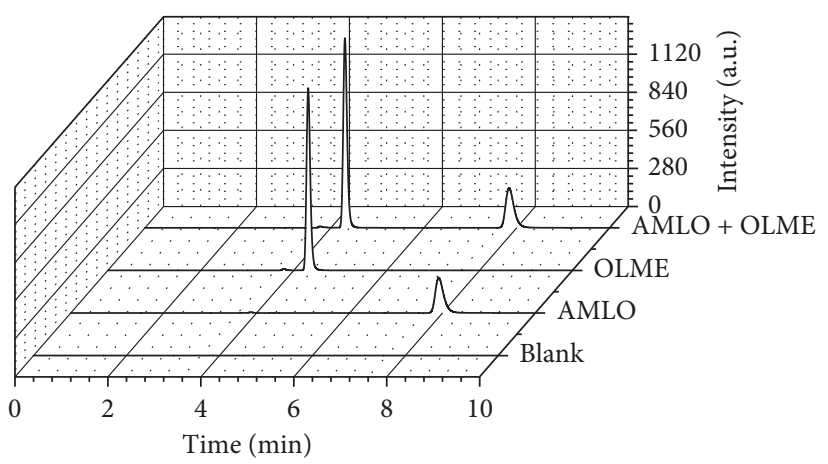

(a)

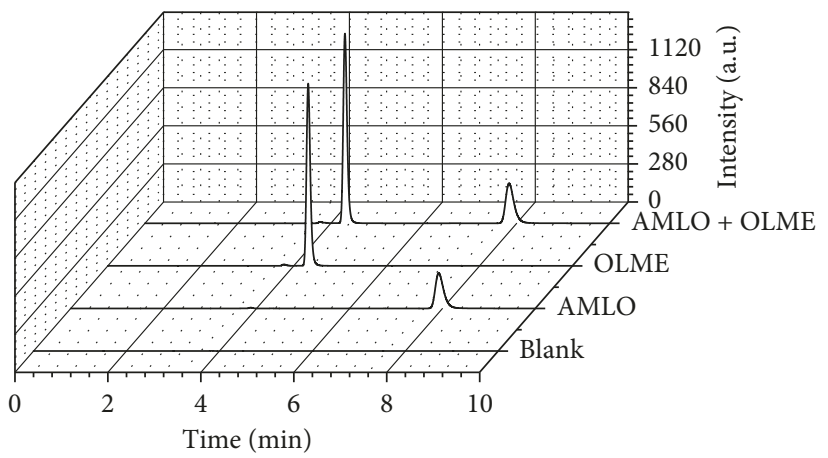

(b)

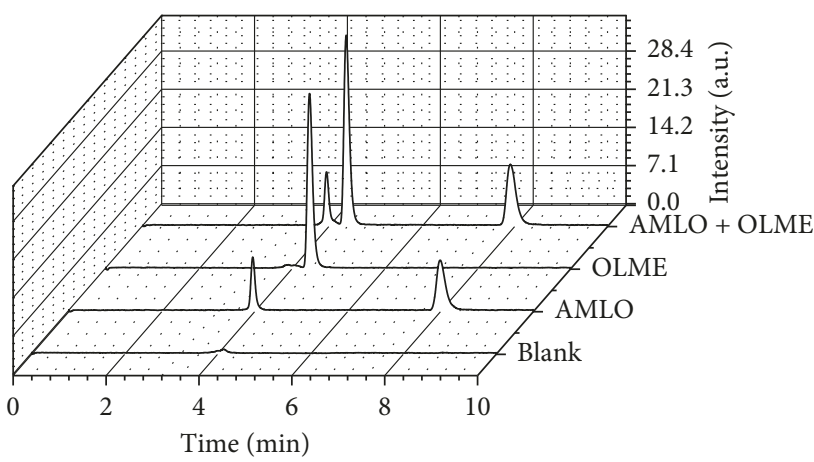

(c)

Figure 2: Chromatograms recorded at (a) $239 \mathrm{~nm}$, (b) $250 \mathrm{~nm}$, and (c) CAD.

a temperature/humidity data logger. And, two portions of samples were also stored for 3 and 6 months in a stability chamber at $40 \pm 0.5^{\circ} \mathrm{C}$ and dry conditions [22].

\section{Results and Discussion}

3.1. Method Validation. The chromatographic results were evaluated using $\mathrm{DAD}$ and $\mathrm{CAD}$. At $\mathrm{DAD}$, the optimum wavelengths selected were $239 \mathrm{~nm}$ and $250 \mathrm{~nm}$ for AMLO and OLME, respectively. The typical chromatograms of AMLO and OLME obtained by the HPLC-based method are presented in Figure 2. The average retention times of OLME and AMLO were 4.336 and $7.854 \mathrm{~min}$, respectively. In the AMLO chromatogram obtained by CAD, there are two peaks: the first at $3.987 \mathrm{~min}$, from besylate fraction, and the second peak at $7.926 \mathrm{~min}$, from AMLO. The OLME 
TABLE 1: Linear and polynomial fit equations for calibration curves for AMLO and OLME determined by HPLC-DAD and HPLC-CAD.

\begin{tabular}{|c|c|c|c|c|c|}
\hline & Range $\left(\mu \mathrm{g} \mathrm{mL}^{-1}\right)$ & Equation & $R^{2}$ & LOD $\left(\mu \mathrm{g} \mathrm{mL}^{-1}\right)$ & LOQ $\left(\mu \mathrm{g} \mathrm{mL}^{-1}\right)$ \\
\hline \multirow{3}{*}{ AMLO } & \multirow{3}{*}{$15-250$} & $\begin{array}{l}\text { DAD-linear } \\
y=0.5862 x+1.4772\end{array}$ & 0.9953 & 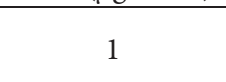 & 4 \\
\hline & & $\begin{array}{c}\text { CAD-linear } \\
y=0.0221 x-0.0356\end{array}$ & 0.0083 & 4 & 10 \\
\hline & & $\begin{array}{c}\text { CAD-polynomial } \\
y=-2.10^{-5} x^{2}+0.0271 x+0.1454\end{array}$ & 0.9994 & 4 & 10 \\
\hline \multirow{3}{*}{ OLME } & \multirow{3}{*}{$25-500$} & $\begin{array}{c}\text { DAD-linear } \\
y=0.6918 x+4.1201\end{array}$ & 0.9958 & 1 & 10 \\
\hline & & $\begin{array}{c}\text { CAD-linear } \\
y=0.0159 x-0.817\end{array}$ & 0.9908 & 5 & 15 \\
\hline & & $\begin{array}{c}\text { CAD-polynomial } \\
y=-2 \cdot 10^{-5} x^{2}+0.0257 x+0.2194\end{array}$ & 0.9988 & 5 & 15 \\
\hline
\end{tabular}

TABle 2: Precision and accuracy for AMLO and OLME determined by HPLC-DAD and HPLC-CAD.

\begin{tabular}{cccccccc}
\hline & $\begin{array}{c}\text { Concentration } \\
\text { added }\left(\mu \mathrm{gL}^{-1}\right)\end{array}$ & Recovery (\%) & $\begin{array}{c}\text { DAD }(n=5) \\
\text { RSD intraday (\%) }\end{array}$ & RSD interday (\%) & Recovery (\%) & $\begin{array}{c}\text { CAD }(n=5) \\
\text { intraday (\%) }\end{array}$ & RSD interday (\%) \\
\hline \multirow{3}{*}{ AMLO } & 20 & 95.46 & 0.54 & 0.96 & 95.52 & 0.57 & 0.88 \\
& 40 & 101.85 & 0.56 & 0.81 & 100.72 & 0.49 & 0.85 \\
& 80 & 100.31 & 0.42 & 0.68 & 99.45 & 0.51 & 0.91 \\
\hline \multirow{3}{*}{ OLME } & 50 & 99.34 & 0.48 & 0.89 & 99.22 & 0.52 & 0.43 \\
& 100 & 100.66 & 0.45 & 0.87 & 100.89 & 0.42 & 0.84 \\
\hline
\end{tabular}

$n$ : number of replicates.

chromatogram registered by CAD present only one peak at $4.408 \mathrm{~min}$. The delay observed at retention time registered by $\mathrm{DAD}$ and $\mathrm{CAD}$ occurs because of the additional distance that the flow must travel to reach this detector.

3.1.1. Calibration Curve. The dynamic range and calibration curve were estimated by analyzing AMLO and OLME standards. The calibration curves of AMLO and OLME were built at the range from 15.0 to $250.0 \mu \mathrm{g} \mathrm{mL}^{-1}$ and from 25.0 to $500.0 \mu \mathrm{g} \mathrm{mL}^{-1}$, respectively. The calibration curves were linear with DAD response. The coefficient of determination $\left(R^{2}\right)$ was equal to or better than 0.995 . The relative standard deviation values of the slope were equal to or better than $3 \%$. For each point of calibration standards, the concentrations were recalculated from the equation of the linear regression curves. The calibration curves with CAD data were calculated with linear and polynomial fits (Table 1). The polynomial fit showed better coefficient of determination $\left(R^{2}>0.999\right)$ than linear fit $\left(R^{2}>0.991\right)$. A linear response was not expected, since aerosol charging does not depend directly on the aerosol mass. Although it is known that Corona CAD response is nonlinear within the range of four orders of magnitude, we found that the signal is nearly linear in the examined ranges of analyzed compounds [14-21, 29].

3.1.2. Limit of Detection (LOD) and the Limit of Quantification (LOQ). Determination of the signal-to-noise ratio $(\mathrm{S} / \mathrm{N})$ was performed by comparing the measured signals from samples of known low concentrations of the analyte with those of blank samples and establishing the minimum concentration at which the analyte can be reliably detected. The LOD and LOQ for each calibration curve are presented in Table 1.

3.1.3. Accuracy and Precision. The accuracy of the recovery for AMLO and OLME was evaluated at three concentrations. The mean recoveries for all samples from each run were in the range of $95.46-101.85 \%$ (Table 2). The precisions were calculated from ten consecutive injections of a sample, and the observed RSD values for AMLO and OLME were in the range of $0.42-0.57 \%$. Intermediate precision was calculated from three days, with RSD values in the range of $0.67-0.96 \%$.

3.1.4. Specificity. The evaluation of the specificity of the method can be observed in Figures 2, 3, and 4. Figure 2 shows that the drugs have well-resolved peaks. Observing Figure 3, it can be stated that the excipients do not have peaks in the same retention time as drugs. Figure 4 shows that even in the presence of the excipients, the drug peaks showed no change in retention times and symmetry. The chromatograms show that no significant interfering peaks were observed at the retention times of analytes, and the peaks are well resolved, with resolution $>1.5$. The peak purity match, calculated by software Chromeleon at ternary mixtures assays, was $99.93 \%$ with $0.06 \%$ RSD for AMLO and $98.76 \%$ with $0.08 \%$ RSD for OLME, based on DAD spectra of each run.

3.1.5. Robustness. The robustness of the proposed HPLC method was evaluated by slight changes of the chromatographic parameters including the flow rate $\left( \pm 0.1 \mathrm{~mL} \mathrm{~min}^{-1}\right)$, 


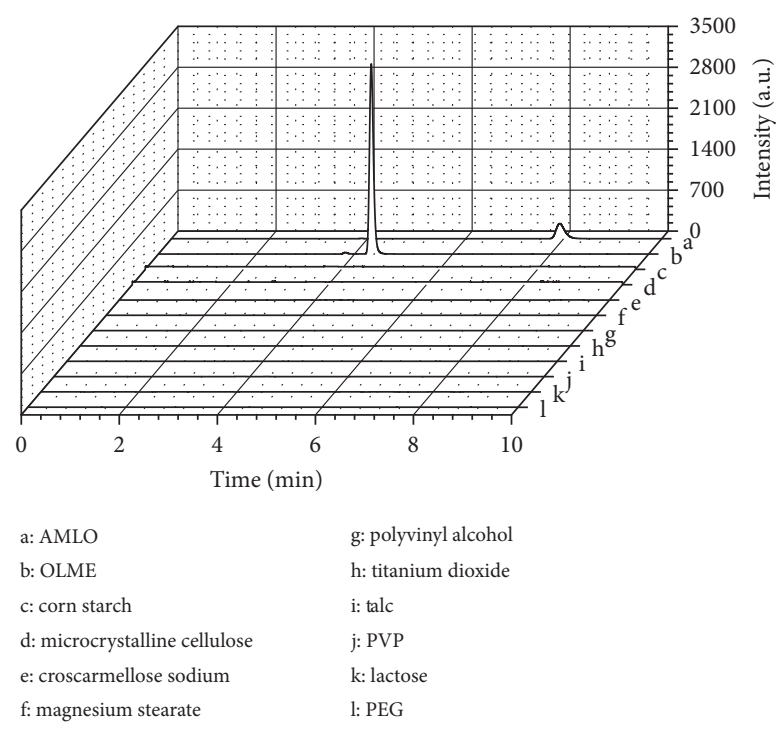

(a)

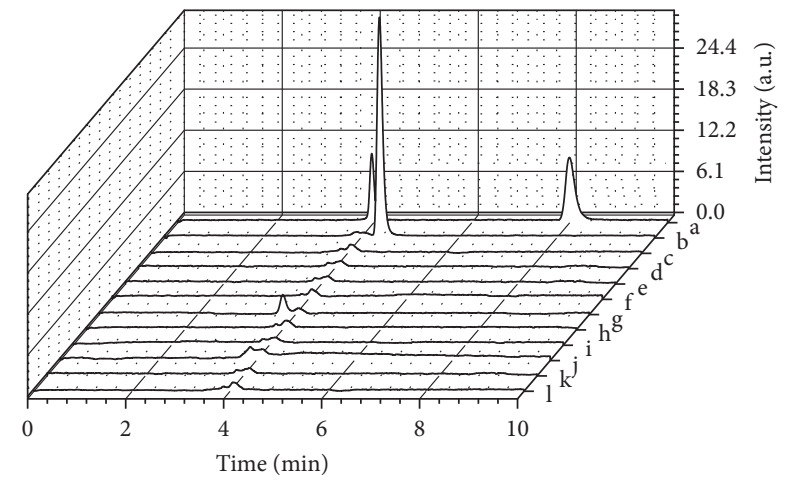

$\begin{array}{ll}\text { a: AMLO } & \text { g: polyvinyl alcohol } \\ \text { b: OLME } & \text { h: titanium dioxide } \\ \text { c: corn starch } & \text { i: talc } \\ \text { d: microcrystalline cellulose } & \text { j: PVP } \\ \text { e: croscarmellose sodium } & \text { k: lactose } \\ \text { f: magnesium stearate } & \text { l: PEG }\end{array}$

(b)

Figure 3: Chromatograms of pure drugs and excipients by (a) DAD and (b) CAD.

mobile phase (proportion of acetonitrile in $60 \pm 2 \%$ ), and column temperature $\left( \pm 5^{\circ} \mathrm{C}\right)$. Afterwards, the drug content and retention time were determined. The results summarized in Table 3 demonstrated that the proposed HPLC method was robust for its intended applications.

3.2. Drug-Excipient Compatibility Study. The chromatograms of AMLO, OLME, and ternary mixtures with excipients at the initial time are presented in Figure 4. In both HPLC detectors, DAD and CAD, none of excipients tested showed interference on the chromatographic profile of the analytes, which makes the methodology adequate for the drug-excipient compatibility study.

After 3 and 6 months of incubation in a stability chamber at $40^{\circ} \mathrm{C} \pm 1^{\circ} \mathrm{C}$ under dry and $75 \% \pm 5 \%$ relative humidity conditions, the samples were analyzed to verify the content
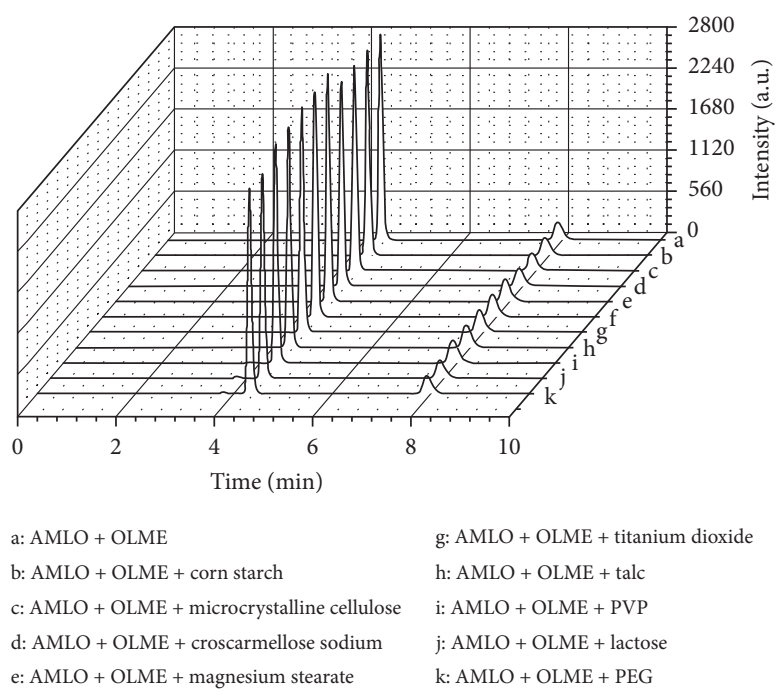

e: AMLO + OLME + magnesium stearate $\quad \mathrm{k}: \mathrm{AMLO}+\mathrm{OLME}+\mathrm{PEG}$

f: AMLO + OLME + polyvinyl alcohol

(a)

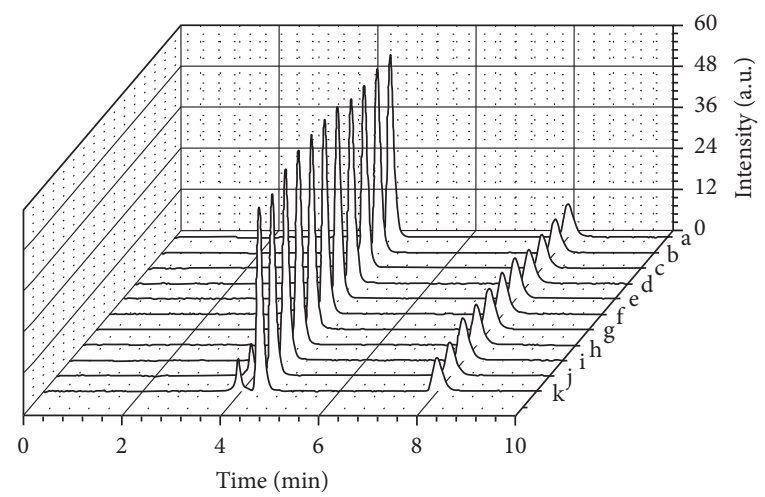
a: AMLO + OLME
b: AMLO + OLME + corn starch
h: AMLO + OLME + talc
c: AMLO + OLME + microcrystalline cellulose
d: AMLO + OLME + croscarmellose sodium
AMLO + OLME + PVP
e: AMLO + OLME + magnesium stearate
$\mathrm{j}:$ AMLO + OLME + lactose
f: AMLO + OLME + polyvinyl alcohol

g: AMLO + OLME + titanium dioxide

(b)

FIgURE 4: Chromatograms of ternary mixtures at initial time recorded by (a) DAD and (b) CAD.

of AMLO and OLME. The samples were prepared so that the expected concentration of AMLO was $100 \mu \mathrm{g} \mathrm{mL}^{-1}$ and OLME was $400 \mu \mathrm{g} \mathrm{mL}^{-1}$, so these values corresponded to $100 \%$ of AMLO and OLME. The reduction of 5\% in these values is indicative of drug degradation, and consequently, chemical incompatibility between the drug and the excipient [22]. The results of drug-excipient compatibility studies are summarized in Tables 4 and 5, obtained by chromatograms of binary mixtures [30].

At $40^{\circ} \mathrm{C} \pm 1^{\circ} \mathrm{C}$ under dry conditions, AMLO and OLME, after 3 and 6 months, did not present changes in concentration recovery in binary and ternary mixtures, indicating that in dry conditions, the AMLO and OLME are compatible with the excipients in the studies.

At $40^{\circ} \mathrm{C} \pm 1{ }^{\circ} \mathrm{C}$ under $75 \% \pm 5 \%$ relative humidity, after 3 months, AMLO and OLME did not present changes in 
TABLE 3: Robustness study for AMLO and OLME determined by HPLC-DAD and HPLC-CAD.

\begin{tabular}{|c|c|c|c|c|c|c|c|c|}
\hline \multirow{3}{*}{ Chromatographic condition } & \multicolumn{4}{|c|}{ AMLO } & \multicolumn{4}{|c|}{ OLME } \\
\hline & \multicolumn{2}{|l|}{$\mathrm{DAD}$} & \multicolumn{2}{|l|}{ CAD } & \multicolumn{2}{|l|}{$\mathrm{DAD}$} & \multicolumn{2}{|l|}{ CAD } \\
\hline & $\begin{array}{l}\text { Concentration } \\
\left(\mu \mathrm{g} \mathrm{mL}^{-1}\right)\end{array}$ & $\begin{array}{c}t_{R} \\
(\mathrm{~min})\end{array}$ & $\begin{array}{l}\text { Concentration } \\
\left(\mu \mathrm{g} \mathrm{mL}^{-1}\right)\end{array}$ & $\begin{array}{c}t_{R} \\
(\min )\end{array}$ & $\begin{array}{l}\text { Concentration } \\
\left(\mu \mathrm{g} \mathrm{mL}^{-1}\right)\end{array}$ & $\begin{array}{c}t_{R} \\
(\mathrm{~min})\end{array}$ & $\begin{array}{l}\text { Concentration } \\
\left(\mu \mathrm{g} \mathrm{mL}^{-1}\right)\end{array}$ & $\begin{array}{c}t_{R} \\
(\mathrm{~min})\end{array}$ \\
\hline Original method & $176.4 \pm 0.1$ & 7.854 & $176.3 \pm 0.1$ & 7.926 & $300.3 \pm 0.1$ & 4.336 & $299.8 \pm 0.1$ & 3.987 \\
\hline Mobile phase: acetonitrile $62 \%$ & $164.7 \pm 0.1$ & 7.556 & $165.3 \pm 0.1$ & 7.976 & $288.8 \pm 0.1$ & 4.327 & $287.5 \pm 0.1$ & 4.76 \\
\hline Mobile phase: acetonitrile 58\% & $165.5 \pm 0.1$ & 7.921 & $166.1 \pm 0.1$ & 8.341 & $309.2 \pm 0.1$ & 4.406 & $310.4 \pm 0.1$ & 4.755 \\
\hline Flow rate: $0.4 \mathrm{~mL} \mathrm{~min}^{-1}$ & $172.5 \pm 0.1$ & 8.291 & $171.4 \pm 0.1$ & 8.711 & $295.9 \pm 0.1$ & 4.512 & $294.7 \pm 0.1$ & 4.860 \\
\hline Flow rate: $0.6 \mathrm{~mL} \mathrm{~min}^{-1}$ & $173.1 \pm 0.1$ & 7.125 & $174.5 \pm 0.1$ & 7.545 & $298.2 \pm 0.1$ & 4.154 & $299.4 \pm 0.1$ & 4.500 \\
\hline Column temperature: $30^{\circ} \mathrm{C}$ & $187.4 \pm 0.1$ & 7.601 & $188.6 \pm 0.1$ & 8.022 & $284.6 \pm 0.1$ & 4.391 & $285.4 \pm 0.1$ & 4.742 \\
\hline Column temperature: $20^{\circ} \mathrm{C}$ & $181.3 \pm 0.1$ & 8.095 & $180.2 \pm 0.1$ & 8.514 & $280.1 \pm 0.1$ & 4.395 & $279.3 \pm 0.1$ & 4.745 \\
\hline
\end{tabular}

$t_{R}$ : retention time.

TABLE 4: Recovery of AMLO and OLME after 3 and 6 months at $40^{\circ} \mathrm{C} \pm 1^{\circ} \mathrm{C}$ under dry condition in binary and ternary mixtures.

\begin{tabular}{|c|c|c|c|c|c|c|c|c|}
\hline \multirow{3}{*}{ Excipient } & \multicolumn{4}{|c|}{ Binary mixtures } & \multicolumn{4}{|c|}{ Ternary mixtures } \\
\hline & \multicolumn{2}{|c|}{3 months } & \multicolumn{2}{|c|}{6 months } & \multicolumn{2}{|c|}{3 months } & \multicolumn{2}{|c|}{6 months } \\
\hline & AMLO (\%) & OLME (\%) & $\operatorname{AMLO}(\%)$ & OLME (\%) & AMLO (\%) & OLME (\%) & AMLO (\%) & OLME (\%) \\
\hline \multirow{2}{*}{ Corn starch } & $102.9 \pm 0.4$ & $101.3 \pm 0.5$ & $98.2 \pm 0.5$ & $97.5 \pm 0.6$ & $99.4 \pm 0.1$ & $101.7 \pm 0.6$ & $98.0 \pm 0.6$ & $102.8 \pm 0.9$ \\
\hline & $100.3 \pm 0.2$ & $101.7 \pm 0.3$ & $101.6 \pm 0.6$ & $98.7 \pm 0.5$ & $99.4 \pm 0.6$ & $100.6 \pm 0.5$ & $98.6 \pm 0.9$ & $103.6 \pm 0.3$ \\
\hline Microcrystalline cellulose & $98.8 \pm 0.5$ & $98.4 \pm 0.7$ & $99.6 \pm 0.5$ & $97.5 \pm 0.7$ & $100.8 \pm 0.6$ & $102.3 \pm 0.9$ & $98.1 \pm 0.8$ & $103.7 \pm 0.5$ \\
\hline Croscarmellose sodium & $109.2 \pm 0.4$ & $99.8 \pm 0.3$ & $97.9 \pm 0.4$ & $103.9 \pm 0.5$ & $101.1 \pm 0.2$ & $101.8 \pm 0.6$ & $98.9 \pm 0.6$ & $101.5 \pm 0.4$ \\
\hline Magnesium stearate & $103.0 \pm 0.5$ & $98.0 \pm 0.6$ & $105.0 \pm 0.7$ & $100.9 \pm 0.4$ & $99.4 \pm 0.6$ & $99.0 \pm 0.2$ & $100.5 \pm 0.4$ & $100.9 \pm 0.8$ \\
\hline Polyvinyl alcohol & $104.6 \pm 0.4$ & $98.0 \pm 0.4$ & $98.6 \pm 0.5$ & $102.5 \pm 0.3$ & $103.1 \pm 0.4$ & $100.2 \pm 0.2$ & $99.6 \pm 0.3$ & $101.9 \pm 0.3$ \\
\hline Titanium dioxide & $104.3 \pm 0.6$ & $99.1 \pm 0.2$ & $101.2 \pm 0.6$ & $100.8 \pm 0.6$ & $99.8 \pm 0.4$ & $102.6 \pm 0.8$ & $99.8 \pm 0.6$ & $102.1 \pm 0.7$ \\
\hline Talc & $98.0 \pm 0.7$ & $98.9 \pm 0.6$ & $98.2 \pm 0.8$ & $99.8 \pm 0.8$ & $103.7 \pm 0.3$ & $98.8 \pm 0.7$ & $99.5 \pm 0.7$ & $101.5 \pm 0.6$ \\
\hline PVP & $101.1 \pm 0.3$ & $99.5 \pm 0.5$ & $100.8 \pm 0.6$ & $100.0 \pm 0.5$ & $98.5 \pm 0.8$ & $101.8 \pm 0.8$ & $101.9 \pm 0.3$ & $101.3 \pm 0.9$ \\
\hline Lactose monohydrate & $100.2 \pm 0.8$ & $103.6 \pm 0.9$ & $97.9 \pm 0.7$ & $103.5 \pm 0.8$ & $98.5 \pm 0.4$ & $98.5 \pm 0.2$ & $100.5 \pm 0.7$ & $99.7 \pm 0.5$ \\
\hline PEG & $99.3 \pm 0.3$ & $98.7 \pm 0.4$ & $101.4 \pm 0.5$ & $99.2 \pm 0.5$ & $102.3 \pm 0.5$ & $99.5 \pm 0.2$ & $99.3 \pm 0.4$ & $102.7 \pm 0.5$ \\
\hline
\end{tabular}

TABLE 5: Recovery of AMLO and OLME after 3 and 6 months at $40^{\circ} \mathrm{C} \pm 1^{\circ} \mathrm{C}$ under $75 \% \pm 5 \%$ relative humidity in binary and ternary mixtures.

\begin{tabular}{|c|c|c|c|c|c|c|c|c|}
\hline \multirow{3}{*}{ Excipient } & \multicolumn{4}{|c|}{ Binary mixtures } & \multicolumn{4}{|c|}{ Ternary mixtures } \\
\hline & \multicolumn{2}{|c|}{3 months } & \multicolumn{2}{|c|}{6 months } & \multicolumn{2}{|c|}{3 months } & \multicolumn{2}{|c|}{6 months } \\
\hline & AMLO (\%) & OLME (\%) & AMLO (\%) & OLME (\%) & AMLO (\%) & OLME (\%) & AMLO (\%) & OLME (\%) \\
\hline Corn starch & $\begin{array}{l}99.3 \pm 0.5 \\
99.0 \pm 0.5\end{array}$ & $\begin{array}{l}102.4 \pm 0.4 \\
100.5 \pm 0.7\end{array}$ & $\begin{array}{c}104.3 \pm 0.2 \\
74.2 \pm 0.4\end{array}$ & $\begin{array}{l}107.1 \pm 0.8 \\
102.5 \pm 0.8\end{array}$ & $\begin{array}{l}101.7 \pm 0.4 \\
100.5 \pm 0.7\end{array}$ & $\begin{array}{l}99.2 \pm 0.9 \\
98.7 \pm 0.9\end{array}$ & $\begin{array}{l}99.2 \pm 0.5 \\
82.7 \pm 0.9\end{array}$ & $\begin{array}{l}110.1 \pm 0.7 \\
101.5 \pm 0.7\end{array}$ \\
\hline Microcrystalline cellulose & $102.3 \pm 0.3$ & $100.4 \pm 0.4$ & $98.2 \pm 0.4$ & $100.8 \pm 0.5$ & $105.9 \pm 0.9$ & $98.2 \pm 0.4$ & $101.7 \pm 0.2$ & $101.2 \pm 0.2$ \\
\hline Croscarmellose sodium & $99.7 \pm 0.8$ & $100.3 \pm 0.5$ & $99.8 \pm 0.3$ & $102.6 \pm 0.3$ & $103.2 \pm 0.8$ & $99.4 \pm 0.6$ & $92.3 \pm 0.3$ & $93.7 \pm 0.5$ \\
\hline Magnesium stearate & $100.8 \pm 0.8$ & $101.6 \pm 0.4$ & $99.6 \pm 0.6$ & $100.4 \pm 0.6$ & $99.0 \pm 0.2$ & $99.5 \pm 0.4$ & $81.2 \pm 0.7$ & $83.1 \pm 0.7$ \\
\hline Polyvinyl alcohol & $98.3 \pm 0.9$ & $98.5 \pm 0.9$ & $100.7 \pm 0.8$ & $102.9 \pm 0.4$ & $98.2 \pm 0.6$ & $100.3 \pm 0.2$ & $84.4 \pm 0.6$ & $83.6 \pm 0.2$ \\
\hline Titanium dioxide & $98.1 \pm 0.9$ & $100.6 \pm 0.5$ & $98.3 \pm 0.4$ & $99.9 \pm 0.5$ & $98.4 \pm 0.6$ & $98.1 \pm 0.4$ & $101.8 \pm 0.3$ & $104.3 \pm 0.4$ \\
\hline Talc & $99.9 \pm 0.7$ & $98.7 \pm 0.6$ & $104.1 \pm 0.5$ & $101.1 \pm 0.3$ & $99.4 \pm 0.3$ & $100.5 \pm 0.5$ & $84.2 \pm 0.4$ & $79.5 \pm 0.6$ \\
\hline PVP & $98.1 \pm 0.9$ & $99.0 \pm 0.7$ & $98.2 \pm 0.7$ & $83.7 \pm 0.9$ & $101.3 \pm 0.7$ & $101.9 \pm 0.4$ & $75.2 \pm 0.5$ & $81.1 \pm 0.9$ \\
\hline Lactose monohydrate & $100.3 \pm 0.6$ & $101.8 \pm 0.6$ & $73.7 \pm 0.3$ & $76.1 \pm 0.6$ & $98.9 \pm 0.9$ & $101.3 \pm 0.8$ & $78.3 \pm 0.8$ & $74.2 \pm 0.8$ \\
\hline PEG & $99.1 \pm 0.7$ & $99.8 \pm 0.5$ & $103.1 \pm 0.3$ & $98.2 \pm 0.9$ & $99.9 \pm 0.5$ & $99.1 \pm 0.6$ & $82.4 \pm 0.7$ & $86.9 \pm 0.4$ \\
\hline
\end{tabular}

concentrations in binary and ternary mixtures. However, after 6 months, the binary mixtures of AMLO with corn starch and lactose monohydrate and of OLME with PVP and lactose monohydrate presented concentration reduction.
And, the ternary mixtures showed concentration reduction of AMLO and OLME in the presence of croscarmellose sodium, magnesium stearate, polyvinyl alcohol, talc, PVP, lactose monohydrate, and PEG. The ternary mixture 
containing corn starch showed concentration reduction only for AMLO. Because of these reductions in concentration of drugs, these excipients are not indicated for preparation of formulations containing AMLO and OLME. Thus, if any of these excipients that presented incompatibility are used in the formulation of AMLO and OLME, this should be kept away from humidity and at milder temperatures.

\section{Conclusions}

The HPLC method for simultaneous determination of AMLO and OLME was validated according to ICH guidelines. The Corona CAD detector was found to be a powerful tool and, because it is relatively recent, has few validated methodologies.

The DAD presents lower LOD and LOQ than CAD. However, both detectors present satisfactory accuracy, precision, specificity, and robustness. The principal advantage of CAD over DAD is the fact that it is a detector independent of the chemical structure and optical properties. CAD allows the quantification even when there is no standard availability because it produces similar response for different compounds, since the detector measures the amount of charge, which is proportional to the amount of analyte $[14,15]$.

The drug-excipient compatibility study showed that at $40^{\circ} \mathrm{C}$, under dry conditions, there is no incompatibility, indicating that the tested excipients can be used at formulations containing AMLO and OLME, provided they are stored away from humidity. At $40^{\circ} \mathrm{C}$, under $75 \%$ of relative humidity, the excipients such as corn starch, croscarmellose sodium, magnesium stearate, polyvinyl alcohol, talc, PVP, lactose monohydrate, and PEG showed chemical incompatibility with AMLO and OLME, and because of it these excipients are not indicated for the preparation of formulations of AMLO and OLME. Thus, if they are used, the formulation should be kept away from humidity and at milder temperatures.

\section{Conflicts of Interest}

The authors declare that they have no conflicts of interest for this research.

\section{Acknowledgments}

This work was supported by CAPES and FAPEMIG.

\section{References}

[1] Pfizer Canada Inc., Norvasc-Product Monograph, pp. 1-40, Pfizer Canada Inc., Kirkland, Québec, QC, Canada, 2013.

[2] S. Shah, D. Kawade, S. Arora, A. Asnani, S. Dangre, and S. Yende, "Simultaneous quantitative analysis of olmesartan medoxomil and amlodipine besylate in plasma by highperformance liquid chromatography technique," Journal of Young Pharmacists, vol. 4, no. 2, pp. 88-94, 2012.

[3] N. Kanwal, I. U. Khan, E. Hussain, S. Farid, and O. Şahin, "Efficient syntheses, crystal structure, thermal and biological evaluation of amlodipine 4-chlorobenzoyl, 4-chlorobenzene and 2,5-dichlorobenzene sulfonamide derivatives," Comptes Rendus Chimie, vol. 19, no. 5, pp. 594-603, 2016.
[4] Merck Canada Inc., Olmetec-Product Monograph, pp. 1-25, Merck Canada Inc., Kirkland, Québec, QC, Canada, 2013.

[5] P. Manoria, P. Manoria, and P. Manoria, "Olmesartan medoxomil: a clinical review," Indian Heart Journal, vol. 58, no. 3, pp. 282-286, 2006.

[6] D. Norwood, E. Branch, B. Smith, and M. Honeywell, "Olmesartan medoxomil for hypertension: a clinical review," Pharmacy and Therapeutics, vol. 27, no. 12, pp. 611-618, 2002.

[7] S. F. Ma, M. Anraku, Y. Iwao et al., "Hydrolysis of angiotensin II receptor blocker prodrug olmesartan medoxomil by human serum albumin and identification of its catalytic active sites," Drug Metabolism and Disposition, vol. 33, no. 12, pp. 19111919, 2005.

[8] Governo do Estado de São Paulo-Secretaria da Saúde, Medicamentos anti-hipertensivos, 2015. http://www.saude.sp. gov.br/resources/ses/perfil/gestor/homepage//linhas-de-cuidadosessp/hipertensao-arterial-sistemica/anexos/medicamentosantihipertensivos.pdf.

[9] USP, “Amlodipine besylate tablets," United States Pharmacopeial Convention, 2011.

[10] W. Y. Qi, Q. Zhao, J. Jiang, and P. Hu, "Simultaneous determination of olmesartan and amlodipine in human plasma and urine by ultra performance liquid chromatography tandem mass spectrometry," Journal of Chromatography B, vol. 938, pp. 27-34, 2013.

[11] P. S. Jain, M. K. Patel, A. P. Gorle, A. J. Chaudhari, and S. J. Surana, "Stability-indicating method for simultaneous estimation of olmesartan medoxomile, amlodipine besylate and hydrochlorothiazide by RP-HPLC in tablet dosage form," Journal of Chromatographic Science, vol. 50, no. 8, pp. 680687, 2012.

[12] S. S. Qutab, S. N. Razzaq, M. Ashfaq, and I. U. Khan, "Simultaneous quantitation of olmesartan medoxomil and amlodipine besylate in combined tablets using HPLC," Journal of the Chilean Chemical Society, vol. 54, no. 3, pp. 234-237, 2009.

[13] K. R. Patil, V. P. Rane, J. N. Sangshetti, R. D. Yeole, and D. B. Shinde, "Stability indicating LC method for the simultaneous determination of amlodipine and olmesartan in dosage form," Journal of Chromatographic, vol. 48, no. 7, pp. 601-606, 2010.

[14] S. Almeling, D. Ilko, and U. Holzgrabe, "Charged aerosol detection in pharmaceutical analysis," Journal of Pharmaceutical and Biomedical Analysis, vol. 69, pp. 50-63, 2012.

[15] T. Vehovec and A. Obreza, "Review of operating principle and applications of the charged aerosol detector," Journal of Chromatography A, vol. 1217, no. 10, pp. 1549-1556, 2010.

[16] Q. Xu, S. Tan, and K. Petrova, "Development and validation of a hydrophilic interaction chromatography method coupled with a charged aerosol detector for quantitative analysis of nonchromophoric a-hydroxyamines, organic impurities of metoprolol," Journal of Pharmaceutical and Biomedical Analysis, vol. 118, pp. 242-250, 2016.

[17] P. K. Ragham and K. B. Chandrasekhar, "Development and validation of a stability-indicating RP-HPL C-CAD method for gabapentin and its related impurities in presence of degradation products," Journal of Pharmaceutical and Biomedical Analysis, vol. 125, pp. 122-129, 2016.

[18] J. Fibigr, D. Šatínský, and P. Solich, "A UHPLC method for the rapid separation and quantification of phytosterols using tandem UV/Charged aerosol detection-a comparison of both detection techniques," Journal of Pharmaceutical and Biomedical Analysis, vol. 140, pp. 274-280, 2017. 
[19] A. G. Pereira, F. B. D’Avila, P. C. L. Ferreira, M. G. Holler, R. P. Limberguer, and P. E. Froehlich, "Method development and validation for determination of cocaine, its main metabolites and pyrolytic products by HPLC-UV-CAD," Chromatographia, vol. 79, no. 3-4, pp. 179-187, 2016.

[20] O. Wahl and U. Holzgrabe, "Impurity profiling of ibandronate sodium by HPLC-CAD," Journal of Pharmaceutical and Biomedical Analysis, vol. 114, pp. 254-264, 2015.

[21] K. Stypulkowska, A. Blazewicz, A. Brudzikowska, M. WarownaGrzeskiewicz, K. Sarna, and Z. Fijalek, "Development of high performance liquid chromatography methods with charged aerosol detection for the determination of lincomycin, spectinomycin and its impurities in pharmaceutical products," Journal of Pharmaceutical and Biomedical Analysis, vol. 112, pp. 8-14, 2015.

[22] ICH Q6A, "Specifications: test procedures and acceptance criteria for new drug substances and new drug products: chemical substances," 1999.

[23] WHO, "The importance of pharmacoviligance: safety monitoring of medicinal products," 2002.

[24] V. Kumar, R. P. Shah, S. Malik, and S. Singh, "Compatibility of atenolol with excipients: LC-MS/TOF characterization of degradation/interaction products, and mechanisms of their formation," Journal of Pharmaceutical and Biomedical Analysis, vol. 49, no. 4, pp. 880-888, 2009.

[25] T. Júlio, I. F. Zâmara, J. S. Garcia, and M. G. Trevisan, "Compatibility of sildenafil citrate and pharmaceutical excipients by thermal analysis and LC-UV," Journal of Thermal Analysis and Calorimetry, vol. 111, no. 3, pp. 20372044, 2013.

[26] ICH Q2 (R1), "Validation of analytical procedures: text and methodology," 2005.

[27] L. Rystov, R. Chadwick, K. Krock, and T. Wang, "Simultaneous determination of Maillard reaction impurities in memantine tablets using HPLC with charged aerosol detector," Journal of Pharmaceutical and Biomedical Analysis, vol. 56, no. 5, pp. 887-894, 2011.

[28] M. Ribani, C. B. G. Bottoli, C. H. Collins, I. C. S. F. Jardim, and L. F. C. Melo, "Validação em métodos cromatográficos e eletroforéticos," Quimica Nova, vol. 27, no. 5, pp. 771-780, 2004.

[29] A. Błazewicz, Z. Fijałek, M. Warowna-Grześkiewicz, and M. Jadach, "Determination of atracurium, cisatracurium and mivacurium with their impurities in pharmaceutical preparations by liquid chromatography with charged aerosol detection," Journal of Chromatography A, vol. 1217, no. 8, pp. 1266-1272, 2010.

[30] A. M. Brondi, Aplicação de análises térmicas em fraude de alimentos e estudo de pré-formulação farmacêutica, Doctoral dissertassion, Universidade Federal de Alfenas, Alfenas, Brazil, 2017. 

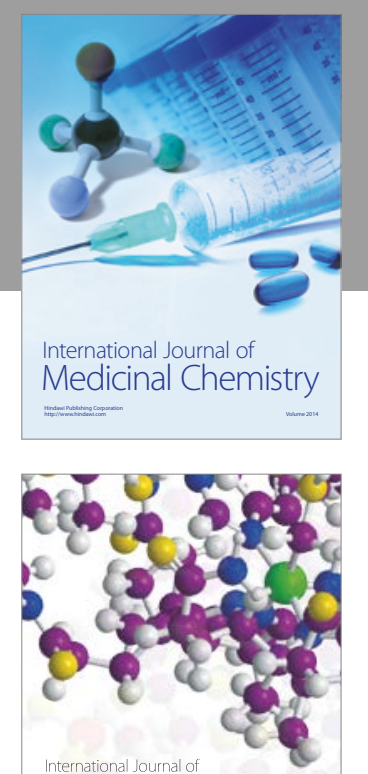

Carbohydrate Chemistry

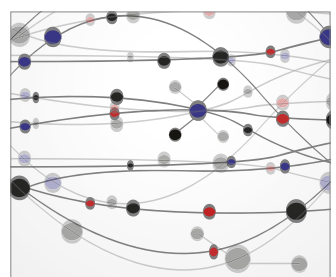

The Scientific World Journal
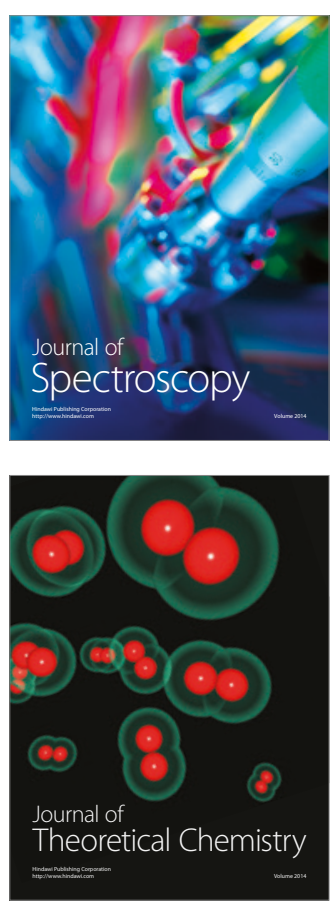
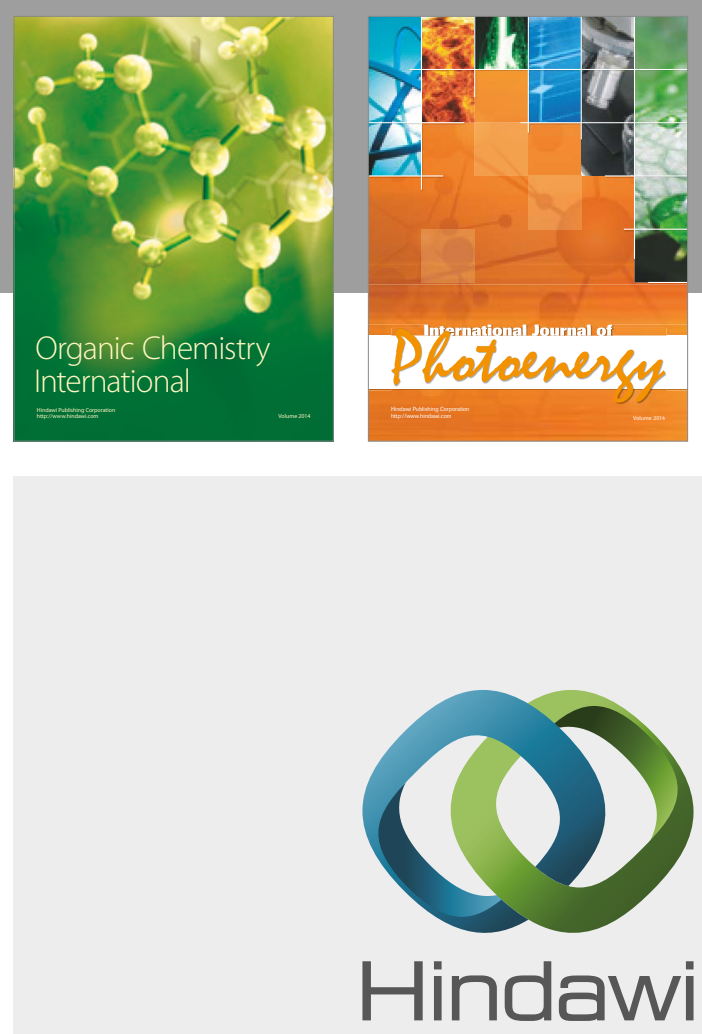

Submit your manuscripts at

https://www.hindawi.com

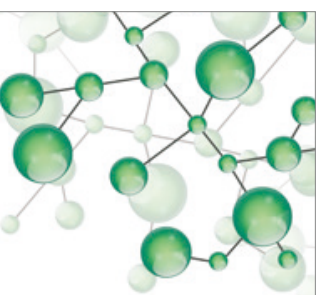

International Journal of

Inorganic Chemistry

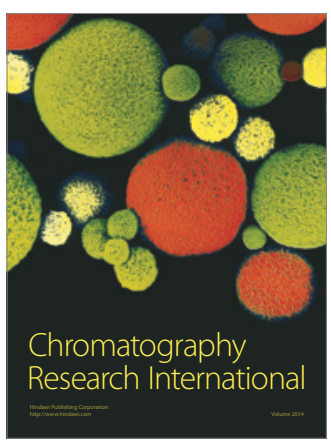

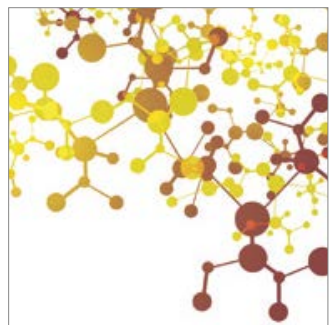

Applied Chemistry
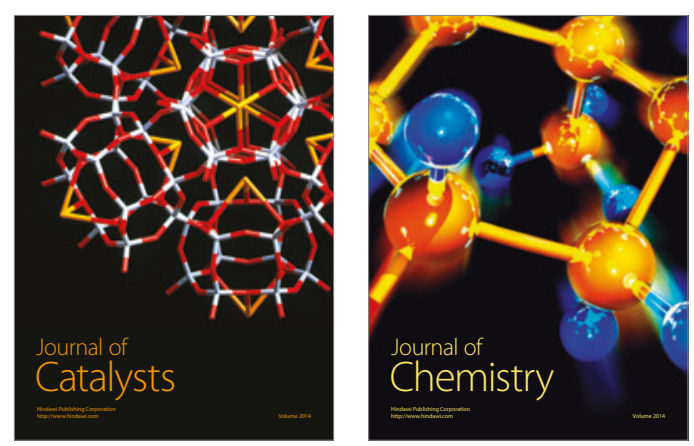
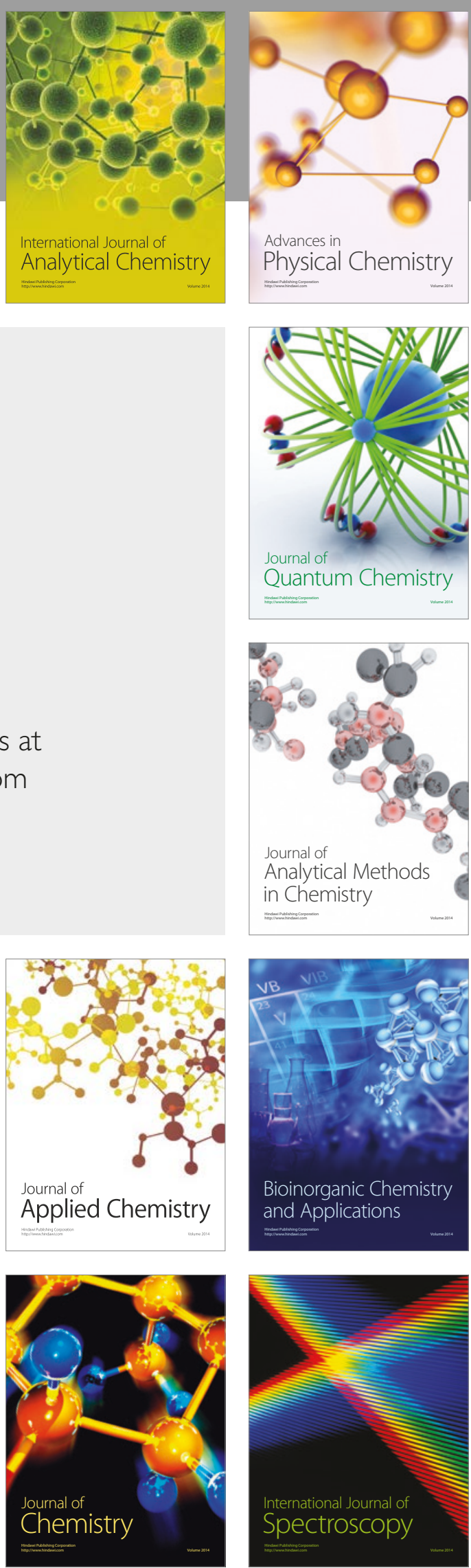